\title{
Commentary
}

\section{Towards a More Sustainable Response: Strengthening the Social Agenda in the Human Immunodeficiency Virus Infection and Acquired Immune Deficiency Syndrome Epidemic}

\author{
Jennifer Knight-Johnson, MA, MPH, PhD* \\ Public Health Analyst, Mitchellville, Maryland 2072I, USA \\ "Corresponding author \\ Jennifer Knight-Johnson, MA, MPH, PhD \\ Public Health Analyst, Mitchellville, Maryland 2072I, USA;Tel. I-240-273-8173; E-mail: jennic4@yahoo.com
}

\author{
Article information

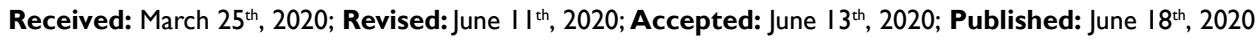

\section{Cite this article}

Knight-Johnson J.Towards a more sustainable response: Strengthening the social agenda in the human immunodeficiency virus infection and acquired immune deficiency syndrome epidemic. HIVIAIDS Res Treat Open J. 2020; 7(I): 3-4. doi: I0. I7I40/HARTOJ-7-I 32

$\mathrm{T}$ The human immunodeficiency virus infection and acquired immune deficiency syndrome (HIV/AIDS) response has made significant strides in preventing the spread of the epidemic globally. Many of the achievements could not have happened without the resilience of the people living with HIV/AIDS (PLHIV) community, the funding and technical support of the donor community including public/private partnerships, the tenacity of the Governments (national response), the relentless outreach of the Non Governmental Organization (NGO) community and their networks, the untiring efforts of health care providers, and the activism of grassroots movements. The focus has shifted from an emergency response to achieving epidemic control ${ }^{1}$ and the 95-95-95 targets, set globally. We are not there yet. The gains have been slowing, as declines in new infection rates are not consistent across countries, ${ }^{2}$ the capability to retain patients in care is suboptimal, antiretroviral treatment (ART) coverage has not reached established targets, and viral suppression rates are struggling to attain optimal levels in many countries.

There has been a dramatic shift in emphasis towards a more targeted approach to reach geographic locations, and the populations most likely to transmit the disease. There has also been an increased emphasis on combination prevention, case finding, contact tracing, diagnostic testing, and expanded treatment regimens which are scientifically proven to improve the efficacy and tolerability for the patients in care. ${ }^{3}$ The question is how far will these interventions help to accomplish the gold standard in which individuals, communities, the society, is sustainable and self-sufficient?
A greater emphasis on the social imperatives that impact HIV prevention care and treatment should be further explored. The social agenda can play a greater role in the policy directives and the operationalization of our interventions. It provides a strategic framework and a conduit for the intersection with how human beings behave in society and the wider social context in which people live. ${ }^{4}$ The social includes, how we circumvent personal relationships; engage in social institutions; and cultural configurations; our role in our of families and households; relationships with men, women, and children; response to HIV/AIDS discrimination and its impact on the individual ${ }^{5}$ (the patient); the social interactions of the individual and the group; and the welfare of human beings, as members of society. Social also means targeting our interventions to society or in the way society is organized. Here are also the structural interventions in prevention which include addressing gender inequalities, homophobia, stigma, and discrimination. ${ }^{6}$ These are critical interventions. In addition, there are the social determinants of health and by extension the social determinants of HIV/AIDS which incorporates lifestyle factors, social support systems, living and working conditions.

Addressing the social norms, processes and structural approaches are no accident of history.

Reflecting on the beginning of the epidemic reminds us that there was a greater emphasis on the "modes of transmission" rather than the social contexts around HIV prevention, care, and treatment. This was a missed opportunity as relationships, patterns 
of marriage, family life, the sexual socialization of children, intergenerational modalities, gender imperatives, race, ethnicity, social class, inequities, power dynamics are embedded in communities that give the HIV virus a strong position for rapid transmission.

Multiple interventions exist to address HIV/AIDS, and only a minority pays sufficient attention to the social processes. These are the ones most likely to prompt the lasting changes needed to protect communities against the consequences of the disease. These are the ones that promulgate lasting changes that endure and are sustainable.

\section{REFERENCES}

1. U.S. President's Emergency Plan for AIDS Relief. PEPFAR2019 Annual Report to Congress Web site. https://www.state.gov/ wp-content/uploads/2019/09/PEPFAR2019ARC.pdf. Accessed March 2, 2020.

2. Global AIDS Update 2018. Miles to go Closing Gaps and Breaking Barriers Righting Injustice. Web site: https://www.unaids.org/ sites/default/files/media_asset/miles-to-go_en.pdf. Accessed
March 10, 2020.

3. PEPFAR 2019 Country Operational Plan Web site. https:// www.state.gov/wp-content/uploads/2019/08/PEPFAR-FiscalYear-2019-Country-Operational-Plan-Guidance.pdf. Accessed March 8, 2020.

4. Harlambos M, Holborn M, Chapman S, Moore S. Haralambos And Holborn - Sociology Themes And Perspectives. $8^{\text {th }}$ ed. London, UK: Collins; 2013.

5. Danziger R. The social impact ofHIV/AIDS in developing countries. Soc Sci Med. 1994; 39(7): 905-917. doi: 10.1016/02779536(94)90203-8

6. AVERT 2016 HIV and AIDS social Issues - Global Information and Education on HIV and AIDS Web site. https://www.avert. org/professionals/hiv-social-issues. Accessed March 5, 2020.

7. Skolnik R. Global Health 101. $4^{\text {th }}$ ed. Burlington, MA, USA: Jones \& Bartlett; 2019. 